\title{
The Influence of The Implementation of School Literacy Movement (SLM) on Students' Reading Interest In Elementary School
}

\author{
Muh. Faisal ${ }^{1}$, Khaerunnisa ${ }^{2}$, Ahmad Syawaluddin ${ }^{3}$ \\ \{ $\underline{\text { muhfaisal77@gmail.com }}{ }^{1}$, kharnisharisah81@gmail.com ${ }^{2}$, Syawaluddinahmad@unm.ac.id ${ }^{3}$ \} \\ ${ }^{1,2,3}$ Elementary School Teacher Education FIP UNM, Indonesia
}

\begin{abstract}
Abstarct. This study discusses the influence of the implementation of school literacy movement on the reading interest of students in SD Inpres Unggulan BTN Pemda Kota Makassar. This study aims to describe the implementation of SLM in elementary school, to find out the overview of elementary students' interest in reading, to find out the influence of SLM application on elementary students' reading interest. This research approach is quantitative with the type of Ex-post facto research. The population in this study was 62 students while the sample was the entire population. The instrument used in this study was questionnaire. The analysis techniques used were descriptive statistical analysis and inferential statistical analysis. The results showed the influence of the school literacy movement (SLM) on students' reading interest. Based on the results of data analysis using descriptive statistics for the school literacy movement (SLM) variable, the average value of 60.85 is in the moderate category with the lowest questionnaire score 50 and the highest score 69 . In the variable of students' reading interest, an average score of 81.11 is in the moderate category with the lowest test score 50 and the highest score 96 . The results of inferential statistical analysis (Simple Linear Regression Analysis) obtained Fcount> Ftable (118.022> 4.00). Thus it can be concluded that there is an influence of the school literacy movement (SLM) on students' reading interest in SD Inpres Unggulan BTN Pemda Kota Makassar.
\end{abstract}

Keywords: School Literacy Movement (SLM), Students’ Reading Interest.

\section{INTRODUCTION}

Society and language are two things that have a very close relationship. There is no society without language, and vice versa, there will be no language without society. Language is a means of interaction in social life. Interaction in society will not be carried out properly without using language. This is in line with the function of language in general as a means of 
social communication. Therefore, the continuity of communication in society is greatly supported by the existence of language.

Good communication is supported by language skills, both oral and written. Good communication will run if the message from the speaker can be understood by the listener in accordance with the intended purpose. The use of language in communication can also reflect one's thoughts. The more skilled a person is in language, the brighter and clearer his mind is. Language skills can only be acquired and mastered by lots of practice. Practicing language skills also means thinking skills (Tarigan, 1990).

Language skills in the curriculum at school include four aspects, namely: (1) listening skills, (2) speaking skills, (3) reading skills, and (4) writing skills. These four language skills cannot be separated. Of the four language skills, reading skills are one of the earliest skill that students really need to master in elementary school. These skills are needed by students as a foundation, vehicle, and absolute requirements for students to study in further science. Therefore, reading is one of the main activities in learning activities. In addition, students are required to conduct reading activities on almost all subjects.

However, the problem now is the low ability and interest in reading of students in Indonesia. The results of international research, the Program for International Student Assessment (PISA) in 2015 on students' reading ability revealed that the reading ability of students in Indonesia ranks 69th out of 76 countries surveyed. That result is lower than Vietnam which ranks 12th of the total countries surveyed (https://www.oecd.org/pisa/pisa2015). In addition, the results of the most recent Littered Nation In the World 2016 study showed that interest in reading in Indonesia was ranked 60 out of 61 countries (Miller and McKenna, 2016).

In connection with this, in 2013 the Ministry of Education and Culture through Ministerial Regulation number 23 of 2013 launched a School Literacy Movement (SLM) to assist students in fostering a culture of reading and writing in the school environment. SLM has an advantage in enhancing student literacy culture. In the Ministry of Education and Culture (2016a: 3) it is stated that:

SLM was developed based on nine priority agendas (Nawacita) related to the duties and functions of the Ministry of Education and Culture, specifically Nawacita numbers 5,6,8, and 9. The Nawacita items meant are (5) improving the quality of life of people and people of Indonesia; (6) increasing people's productivity and competitiveness in international markets so that the Indonesian people can advance and rise together with other Asian nations; (8) revolutionizing the nation's character; (9) strengthening diversity and Indonesian social restoration. The four Nawacita items are closely related to the literacy component as capital for the formation of quality, productive and competitive, character and nationalist human resources.

According to Faizah (2016: 2) School Literacy Movement (SLM) is the ability to access, understand, and use something intelligently through various activities, including reading, seeing, listening, writing and / or speaking. Related to that, Alwasilah, (2012: 177) said that "teaching literacy basically makes human beings who are functionally capable of reading, being educated, intelligent, and showing appreciation for literature."

Based on the explanation above, it is necessary to conduct an in-depth study to see the effectiveness of the government program in fostering students' reading culture or interest in elementary school. For this reason, the authors are interested in conducting research to find out whether there is an influence of the School Literacy Movement (SLM) on elementary students' reading interest. 


\section{The Nature of Literacy}

Literacy activities are synonymous with reading and writing activities. This is consistent with what is written in the 7th Edition Oxford Advanced Learne's Dictionary (Alawasilah, 2012: 159) that "literacy is the ability to read and write". The same opinion was stated by Barton (Nurgiyantoro, 2005: 120) that "the term literacy has various meanings, and one of the meanings which can be given to it is" being able to read and write.

The Prague Declaration in 2003 stated that literacy also covers how a person communicates in society. Literacy also means social practices and relationships related to knowledge, language and culture (UNESCO, 2003). Related to this, Kern (2000) argues that literacy is narrowly defined as the ability to read and write. Furthermore, this ability is also related to habituation in reading and appreciating literary works (literature) and evaluating them. However, literacy is broadly related to the ability to think and learn for life to survive in social and cultural environment.

According to Kern (2000) defines the term literacy comprehensively, namely Literacy is the use of socially-, and historically-, and culturally-situated practices of creating and interpreting meaning through texts. It entails at least a tacit awareness of the relationships between textual conventions and their context of use and, ideally, the ability to reflect critically on those relationships. Because it is purpose-sensitive, literacy is dynamic not static - and variable across and within discourse communities and cultures. It draws on a wide range of cognitive abilities, on knowledge of written and spoken language, on knowledge of genres, and on cultural knowledge.

Literacy is the use of social, historical and cultural situations and practices in creating and interpreting meaning through texts. The meaning of the text above includes written text and oral text.

A broader notion of literacy was put forward by Hubble (2016), namely: Literacy includes language skills, numeracy, understanding of images, computer literacy and various other basic means of communicating, understanding, conveying, gaining useful knowledge, and taking advantage of various dominant symbol systems of a culture, including the ability to gain knowledge through technology and the ability to assess various contexts of complex or complex situations.

The understanding of literacy based on the context of its use is stated by Baynham (1995: 9) that literacy is an integration of listening, speaking, writing, reading, and critical thinking skills. Cooper (1993) defines literacy from an ideological standpoint of scholarship which states that literacy is "mastery of, or fluent control over, a secondary discourse." speak, read and write.

Based on the description above, it can be stated that literacy is (1) literacy or literacy skills; (2) the ability to integrate listening, speaking, reading, writing and thinking; (3) ability to be ready to be used in mastering new ideas or ways to learn them; (4) ability tools to support its success in an academic or social environment; (5) reading and writing performance abilities that are always needed; (6) the competence of an academic in understanding professional discourse.

\section{Literacy Component}

Conceptually, literacy is understood more than just reading and writing, but includes thinking skills using knowledge sources in print, visual, digital, and auditory forms. In this era, the ability in question is as information literacy. Clay (2001) and Ferguson (www.bibliotech.us) describe that the information literacy component consists of early 
literacy, basic literacy, library literacy, media literacy, technological literacy, and visual literacy. In the Indonesian context, early literacy is needed as a basis for obtaining the next level of titration. The literacy component is explained as follows:

The parties that play an active role in implementing the literacy component are presented in the following table:

\author{
No. Literacy Components Active Participants \\ $1 \quad$ Early age Literacy \\ Parents/families, teachers, tutors, caregivers \\ 2 Basic Literacy $\quad$ Formal Education \\ 3 Library Literacy Formal Education \\ $4 \quad$ Technology Literacy \\ Formal Education and Family \\ $5 \quad$ Media Literacy \\ Formal education, family, social \\ Environment \\ 6 Visual Literacy $\quad$ Formal education, family and social environment \\ (Source: Master Book Design for School Literacy Movement )
}

\title{
3.1 School Literacy Movement (SLM)
}

School Literacy Movement (SLM) in the Ministry of Education and Culture (2016a) is the ability to access, understand, and use things intelligently through various activities, including reading, seeing, listening, writing and speaking. Whereas SLM is a comprehensive effort to make schools a learning organization whose citizens are literate throughout life through public engagement.

Based on the guidebook prepared by the Ministry of Education and Culture regarding this policy, SLM has:

\section{a) Philosophical foundation}

The youth pledge of the third item (3) states, "upholding the language of the unity of the Indonesian language which has the meaning of recognizing the existence of hundreds of regional languages that have the right to life and opportunities to use foreign languages according to their needs."

a) This item emphasizes the importance of language learning in nationa education.

b) United Nations Convention on the Rights of the Child in 1989 concerning the importance of using mother tongue. Indonesia, which has various ethnic groups, especially certain microcultures, needs to be facilitated with their mother tongue when they enter low-grade primary education (classes I, II, III).

c) The UN Convention in Praha in 2003 on basic literacy skills and effective library skills is the key for people who are literate in facing the swift flow of information technology. The five essential components of information literacy are basic literacy, library literacy, media literacy, technology literacy, and visual literacy. 


\section{b) Legal Foundation}

The legal basis of the School Literacy Movement contained in the SLM master design are:

a) The 1945 Constitution, Article 31, Paragraph 2: "The government is endeavoring and organizing a national education system that enhances faith and piety and noble character in order to educate the life of the nation, which is regulated by Law."

b) Law of the Republic of Indonesia Number 20 of 2003 concerning the National Education System.

c) Law of the Republic of Indonesia Number 43 of 2007 concerning Library.

d) Law of the Republic of Indonesia Number 24 of 2009 concerning the Flag, Language and Symbol of the State and the National Anthem.

e) Republic of Indonesia Government Regulation Number 32 of 2013 concerning Second Amendment to Government Regulation of the Republic of Indonesia Number 19 of 2005 concerning National Education Standards.

f) Government Regulation Number 24 of 2014 concerning the Implementation of Law Number 43 of 2007 concerning Libraries.

\subsection{Objectives of the School Literacy Movement (SLM)}

The School Literacy Movement in its application has a goal to be achieved. According to Mardiah (2016) SLM aims to strengthen the growth of students' character. In addition to that opinion, Supiandi (2016: 2) states that the School Literacy Movement (SLM) aims to foster a culture of reading and writing (literacy) in school residents, both school principals, students, and teachers, which results in analytical understanding of information, critical, and reflective. The School Literacy Movement (SLM) also aims to create a school environment that is a lifelong learning environment by cultivating reading activities that don't just read and write that don't just write.

The goals of SLM in the Ministry of Education and Culture (2016a), stated that SLM as a movement has goals to be achieved, namely:

\section{a. General purpose}

Developing students' character through the culture of the school literacy ecosystem which is realized in the SLM so that they become lifelong learners.

\section{b. Special purpose}

1) Developing a literacy culture in schools

2) Increasing the capacity of residents and the school environment to be literate.

3) Making the school a fun and child-friendly learning park so that school residents are able to manage knowledge.

4) Maintaining the sustainability of learning by presenting various reading books and accommodating various reading strategies.

Based on these opinions, the aim of SLM is to foster students to become literacy lovers so that they can become lifelong learners and have good character in literacy culture. 


\subsection{Principles of School Literacy Movement (SLM)}

There are seven principles of literacy education taken from the definition of Kern (2000), namely:

\section{a. Literacy involves interpretation}

The writer / speaker and reader / listener participate in interpretive actions, namely: the writer / speaker interprets the world (events, experiences, ideas, feelings, etc.), and the reader / listener then interprets the interpretation of the writer / speaker in the form of his own conception of the world.

\section{b. Literacy involves collaboration}

There is collaboration between the two parties namely writer / speaker and reader / listener. The intended cooperation is in an effort to achieve a mutual understanding. The writer / speaker decides what needs to be written / said or that does not need to be written / said based on their understanding of the reader / listener. While readers / listeners devote their motivation, knowledge, and experience in order to make the writer's text meaningful.

\section{c. Literacy involves convention}

Reading and writing or listening and speaking are determined by cultural (not universal) conventions / agreements that develop through use and are modified for individual purposes. The convention here includes language rules both oral and written.

\section{d. Literacy involves cultural knowledge}

Reading and writing or listening and speaking function in certain systems of attitudes, beliefs, habits, ideals, and values. So that people who are outside a cultural system are vulnerable / at risk of being misunderstood / misunderstood by people who are in the cultural system.

\section{e. Literacy involves solving problems}

Words always cling to the linguistic context and situations that surround them, so the act of listening, speaking, reading, and writing involves trying to imagine the relationships between words, phrases, sentences, units of meaning, texts, and worlds. Efforts to imagine / think / consider this is a form of problem solving.

\section{f. Literacy involves reflection and self-reflection}

Readers / listeners and writers / speakers think about language and its relationships with the world and themselves. After they are in a communication situation they think about what they have said, how to say it, and why to say it.

\section{g. Literacy involves the use of language}

Literacy is not limited to language systems (oral / written) but rather requires knowledge of how language is used both in oral and written contexts to create a discourse / discourse. 
According to the Ministry of Education and Culture (2016a), SLM applied at the elementary level has several principles in its application, namely:

a. In accordance with the stages of student development based on its characteristics.

b. Be carried out in a balanced manner; use a variety of texts and pay attention to students' needs.

c. Take place in an integrated and holistic manner throughout the curriculum area

d. Literacy activities carried out continuously.

e. Involves verbal communication skills.

f. Consider diversity.

Based on this opinion, the SLM principle is concluded as an interaction that occurs between students as readers / listeners and writers / speakers involving several aspects, namely: interpretation, collaboration, convention, cultural knowledge, problem solving, reflection and language developed in accordance with the stages of development and student needs.

\subsection{Stages of Implementation of School Literacy Movement (SLM)}

Lipton (2016) states that there are five stages in planning and fostering school literacy, namely: 1) Designing an educated environment, 2) Guiding student interaction, 3) Improving fluency, 4) Fostering lifelong learning, 5) Assessing student development.

Whereas SLM SD is carried out in three stages to ensure its long-term sustainability. The Ministry of Education and Culture (2016b: 7-85) states that these stages, namely the stage of habituation, development, and learning.

\section{Reading Interest}

\section{Definition of Interest}

According to Sardiman (2012: 76) "Interest is defined as a condition that occurs when someone sees the characteristics or meanings of a situation that is associated with his own desires or needs". Meanwhile according to Syah (2013: 133) "Simply put, interest means a tendency and high enthusiasm or a great desire for something". Expert opinion regarding the notion of interest, stated by Slameto (2013: 57) which defines interest as "a constant tendency to pay attention and remember some activities". Activities that are of interest to students are given constant attention, accompanied by pleasure and a sense of satisfaction is gained. Interest is further explained is a sense of love and interest in a thing or activity, without anyone asking.

Based on some expert opinions above, it can be concluded that interest is an inner attitude from within a person which is a special attention to a certain thing that is created with a full will and a feeling of pleasure that arises from one's inner impulse. Interest can be said as a strong impetus for someone to do everything in realizing the achievement of goals and ideals that become his desire.

\section{Definition of Interest in Reading}

Interest in reading is an encouragement to understand word for word and the content contained in the text of the reading, so that the reader can understand the things set forth in the reading. According to Dalyono (2012: 182) "Interest in reading is the tendency of the soul to 
encourage someone to do something about reading. Interest in reading is indicated by a strong desire to do reading ".

In addition, Rahim (2011: 28) argues that "Interest in reading is a strong desire accompanied by one's efforts to read. People who have a strong interest in reading will manifest in their willingness to get reading material and then read it on their own consciousness ". Meanwhile according to Djamarah (2011: 24) "Interest in reading is the desire and strong will to always read every opportunity or always looking for opportunities to read".

Based on some of the opinions of the experts above, it can be concluded that interest in reading is an activity carried out with full perseverance in order to establish a pattern of communication with oneself to find the meaning of writing and find information to develop intellectuality which is carried out with full awareness and feelings of pleasure arising from within himself. Therefore, the higher one's interest in reading, the stronger their desire to read.

\section{Indicators of Interest in Reading}

The reading interest indicator according to Djali (2014: 121) includes aspects of "Attention, feelings, and responses. Attention is related to the frequency, free time, and number of books read. Feelings are related to feelings of pleasure towards reading habits, whereas responses are related to responses or satisfaction after reading ". Meanwhile, according to Crow and Crow in Shaleh and Wahab (2007: 264), there are several indicators that indicate interest in reading, namely as follows:
a) Feelings of pleasure
b) Concentration
c) Time usage
d) Motivation to read
e) Emotion in reading
f) Efforts to read

\section{Factors Influencing Reading Interest}

Reading culture is an attitude and action for reading, which is carried out regularly and continuously. Interest in reading that began to be developed at an early age and takes place regularly will grow into reading habits. According to Darmono (2007: 217) the factors that influence reading interest are classified into two groups, namely: internal factors and extreme factors.

\section{RESEARCH METHODS}

This research is a type of ex-post facto research which is causality, the independent variable in this study is the Implementation of School Literacy Movement (given the X symbol). While the dependent variable of this study was Elementary Student Reading Interest (given the Y symbol). This can be modeled as follows: 


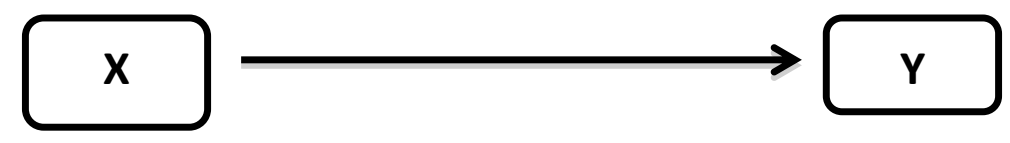

Information:

$\mathrm{X}$ : the application of school literacy movement variable

Y: reading interest variable

The population in this research were all students of the SD Inpres Unggulan BTN Pemda Kota Makassar. Then the samples were students in third and fourth class in SD Inpres Unggulan BTN Pemda Kota Makassar. The number of samples was 63 students (third class were 31 students and fourth class were 32 students). Data collection methods are the methods used to collect data. To get accurate and scientific data, the data collection technique used in this study is Questionnaire.

The data analysis techniques used in this study are descriptive statistics and inferential statistics.

\section{Descriptive Statistical Analysis}

Descriptive statistics are statistics used to analyze data by describing data that has been collected as it is without intending to make generally accepted conclusions or generalizations.

For statistical categorization, researchers used the formula proposed by Saifuddin Azwar, as a categorization of the results of the questionnaire instrument and the results of observations as follows:

Table 4.1 Categorizing

The range

$$
\begin{gathered}
\mathrm{X}<\left(\mathrm{x}^{-}-1.0 \mathrm{SD}\right) \\
\left(\mathrm{x}^{-} 1.0 \mathrm{SD}\right) \leq \mathrm{X}<\left(\mathrm{x}^{-}+1.0 \mathrm{SD}\right) \\
\left(\mathrm{x}^{-}+1.0 \mathrm{SD}\right) \leq \mathrm{X}
\end{gathered}
$$

\section{Categorization \\ Low \\ Moderate \\ Height}

\section{Inferential Statistical Analysis}

Inferential statistics are statistics used to analyze sample data and the results will be generalized (referenced) to the population in which the sample is taken. The need for hypothesis testing, then used to test the truth of this research hypothesis is as follows: 1) Normality Test, 2) Linearity, 3) Simple Linear Regression Analysis

\section{RESEARCH RESULT}

The results of this study will answer three formulations of the problems raised in this study. Problem formulas 1 and 2 use descriptive statistics, while the formulation of the third problem is solved by using inferential statistics using SPSS version 20. Inferential statistical analysis will simultaneously answer the proposed hypothesis.

This research was conducted to determine the influence of school literacy movement on the reading interest of elementary school students in third and fourth class of SDN Unggulan BTN Pemda Kota Makassar. To retrieve data from the two variables, a questionnaire was used. After the data is collected, it is then analyzed using descriptive analysis to find out the 
description of each variable and inferential statistics are used for linearity tests, simple linear regression, and hypothesis tests.

\section{Descriptive Statistical Analysis}

\section{a. Descriptive School Literacy Movement (SLM)}

Based on the results of research conducted at SD Inpres Unggulan BTN Pemda Kota Makassar with the data collection method using questionnaire instrument consisting of 24 statement items given to students in the third and fourth class as many as 62 people, when conducting data analysis the results were obtained that the school literacy movement (SLM) obtained through instruments that are questionnaires from 62 respondents showed that the highest value is 69 and the lowest value is 50 , then the range is 19 , an average of 60.85 with a standard deviation of 4.59 .

The categorization of the implementation of school literacy movement (SLM) in SD Inpres Unggulan BTN Pemda Kota Makassar is as follows:

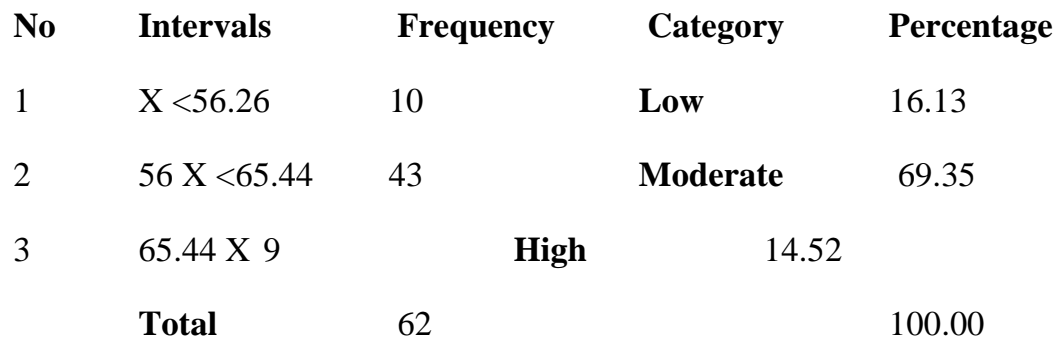

Based on the data, from 62 students as sample it can be seen that the school literacy movement (SLM), reading 15 minutes for students of SD Inpres Unggulan BTN Pemda Kota Makassar, 10 people $(16.13 \%)$ in the low category, 43 people $(69.35 \%)$ are in the moderate category, and 9 people $(14.52 \%)$ are in the high category. When viewed from the average obtained at 60.85 included in the three categories above, it is in the moderate category so it can be concluded that SD Inpres Unggulan BTN Pemda Kota Makassar have a moderate school literacy movement.

\section{b. Descriptive Students' Reading Interest}

Data of students' reading interest obtained through questionnaire consisting of 20 items of statements given to Class III students and Class IV Students of SD Inpres Unggulan BTN Pemda Kota Makassar as many as 62 students obtained descriptive statistical results from 62 respondents, indicating that the interest in reading grade III students and grade IV SD Inpres Unggulan BTN Pemda Kota Makassar which is the highest grade 96 and the lowest value 50, so the range is 46 , an average of 81.11 with a standard deviation of 10.00 .

The level of interest in reading students can be known by categorization, as follows:

$\begin{array}{lllccr}\text { No } & \text { Intervals } & \text { Frequency } & \text { Category } & \text { Percen } \\ 1 & \mathrm{X}<71.00 & & 8 & \text { Low } & 12.90 \\ 2 & 71.00 \mathrm{X}<91.88 & 46 & & \text { Moderate } & 74.19\end{array}$


Table 4.4 shows categories and percentage of students' reading interest as a sample. It can be seen that the students' reading interest is in the form of feelings of pleasure when reading, reading without being told, using the library and trying to have books. There are 8 people $(12,90 \%)$ in the low category, and 46 people $(74.19 \%)$ are in the moderate category, 8 people $(12.90 \%)$ are in the high category, If viewed from the average obtained by 81.11 when included in these three categories are in the moderate category so that it can be concluded that students of the SD Inpres Unggulan BTN Pemda Kota Makassar have a moderate interest in reading.

\section{Inferential Statistical Analysis}

\section{a. Normality Test}

Based on the normality test using Kolmogorov-Smirnov obtained sig values from Kolmogorov-Smirnov for school literacy movement of 0.903 and the value of the results indicates that the results obtained are greater than $0.05(0.389>0.05)$ so it can be concluded that the data is normally distributed. Then the value of sig. for students' reading interest is also greater than $0.05(0.472>0.05)$. So the normality test above shows that the data is normally distributed.

\section{b. Linearity Test}

From this output, a deviation from linearity is obtained with the value of sig. 0.238 is greater than 0.05 which means the data is linear.

\section{c. Simple Linear Regression Analysis}

\section{1) Simple Linear Regression Equation}

Based on the results of the regression test analysis, the constants and equation coefficients are obtained from column $\mathrm{B},=-26,853+1,774 \mathrm{X}$. from the analysis obtained sig. $=0,000$ $<0.05$ or H0 is rejected. Thus the school literacy movement (SLM) on students' reading interest of the SD Inpres Unggulan BTN Pemda Kota Makassar. The regression coefficient of 1.774 states that each time the implementation of school literacy movement variable increases by one, the students' reading interest variable increases by 1,774 with the magnitude of the correlation / relationship (R) value of 0.814 and explains the percentage of the influence of school literacy movement (SLM) on students' reading interest called the coefficient of determination (R2) of 0.663 which implies that the influence of the implementation of school literacy movement (SLM) on students' reading interest is $66.3 \%$ while the remaining $23.7 \%$ is influenced by other variables not included in this study.

$\mathrm{HO}=$ There is no influence of the implementation of school literacy movement (SLM) on students' reading interest.

$\mathrm{H} 1=$ There is an influence of the implementation of school literacy movement (SLM) on students' reading interest.

(a) Determine the Fcount

From the output, it can be obtained Fcount $=118.022$

(b) Determine the value of $\mathrm{F}$ 
The value of $\mathrm{F}$ table can be seen in the statistical table for significant 0.05 with $\mathrm{df} 1=$ $(\mathrm{k}-1)$ and df $2=\mathrm{n}-\mathrm{k}$. so df $1=2-1=1$ and df $2=62-2=60$. The results obtained for Ftable is 4.00

(c) Determine testing criteria

If Fcount $<$ Ftable, then $\mathrm{H} 0$ is accepted

If Fcount $>$ Ftable, then $\mathrm{H} 0$ is rejected

(d) Drawing Conclusions

Because Fcount> Ftable $(118.022>4.00)$ then H0 is rejected so it can be concluded that there is an influence of the implementation of school literacy movement (SLM) on students' reading interest.

\section{d. Hypothesis testing}

In this study the hypothesis test is used to determine whether there is an influence of the implementation of school literacy movement (SLM) on students' interest in reading. The test uses a significance level of 0.05 . The test results can be seen in Table 4.7.

(1) Formulate a hypothesis

H0: There is no significant influence of the implementation of school literacy movement (SLM) on students' reading interest

Hi: There is a significant influence of the implementation of school literacy movement (SLM) on students' interest in reading

(2) Determine significance

The results of data analysis as in table 4.8 show that the significance value is 0,000

(3) Test criteria:

If the significance is $>0.05$, then $\mathrm{H} 0$ is accepted

If the significance is $<0.05$, then $\mathrm{H} 0$ is rejected

(4) Drawing conclusions

Significance value $<0.05(0,000<0.05)$, then $\mathrm{H} 0$ is rejected. So it can be concluded that there is a significant influence of the implementation of school literacy movementa on students' reading interest.

\section{DISCUSSION}

Based on the results of data collection through the school literacy movement (SLM) questionnaire instrument, data were analyzed using descriptive analysis. After analyzing the data, it can be seen that the implementation of school literacy movement (SLM), 10 people were in the low category with a percentage $(16.13 \%), 43$ people were in the moderate category with a percentage $(69.35 \%)$, and 9 people were in the high category with a percentage $(14.52 \%)$. When viewed from the average obtained at 60.85 when included in the three categories, it is in the moderate category so it can be concluded that the students of SD Inpres Unggulan BTN Pemda Kota Makassar have moderate school literacy movements with a $69.35 \%$ percentage with a total of 43 from 62 students.

Reading literacy is one of the main abilities acquired by students in their initial developmental process at school and then becomes the foundation for learning other subjects. This basic ability can also be used to have fun by reading books that interest them, and more 
importantly, in line with the development and growth of their intellect, this basic ability can be used to survive in real life in the wider community. Because of the importance of this ability for the development of this young generation.

Therefore, students' reading interest data obtained through questionnaires and analyzed using descriptive statistical analysis, it can be seen that the students' reading interest at SD Inpres Unggulan BTN Pemda Kota Makassar, there are 8 people $(12.90 \%)$ are in the low category, and 46 people are in the moderate category with a percentage $(74.19 \%), 8$ people are in the high category with a percentage $(12.90 \%)$, if viewed from the average average of 81.11 if it is included in the three categories, it is in the moderate category so it can be concluded that the students' reading interest at SD Inpres Unggulan BTN Pemda Kota Makassar was moderate with a percentage of $74.19 \%$ from 46 out of 62 student.

Then to find out the influence of the implementation of School Literacy Movement (SLM) on students' reading interest in SD Inpres Unggulan BTN Pemda Kota Makassar as the third problem formulation, the type of analysis used is inferential statistical analysis using simple linear regression analysis obtained regression equation $=-26,853+1,774 \mathrm{X}$, The regression coefficient of 1.774 states that each time the school literacy movement variable (SLM) increases by one, the student reading interest variable increases by 1,774 .

From the results of hypothesis testing which shows that the $\mathrm{F}$ value obtained from the calculation of Fcount> Ftable (118.022> 4.00), then H0 is rejected so it can be concluded that there is an influence of the implementation of school literacy movement (SLM) on students' reading interest in SD Inpres Unggulan BTN Pemda Kota Makassar and the percentage of the contribution of reading interest towards reading comprehension is $66.3 \%$ while the remaining $23.7 \%$ is influenced by other variables not included in this study. Based on the description it can be concluded that the implementation of school literacy movement (SLM) is one of the factors that influence students' reading interest.

\section{REFERENCE}

Alwasilah, A.Chaedar. 2012. Pokoknya Rekayasa Literasi. Bandung: PT Kiblat Buku Utama Arikunto, Suharsimi. Prosedur Penelitian Suatu Pendekatan Praktik. Jakarta: Rineka Cipta.

Dalman. 2014. Keterampilan Membaca. PT . Rajagrafindo Persada. Jakarta.

Dalyono. 2012. Psikologi Pendidikan. Jakarta: PT. Rineka Cipta.

Dalyono. 2012. Psikologi Pendidikan. PT. Rineka Cipta. Jakarta.

Darmono. 2007. Perpustakaan Sekolah : Pendekatan aspek manjemen dan tata kerja. Grasindo. Jakarta.

Djaali. 2014. Psikologi Pendidikan. Bumi Aksara. Jakarta.

Djamarah, Syaiful Bahri. 2011. Psikologi Belajar. PT. Rineka Cipta. Jakarta.

Faizah, Dewi Utama dkk. 2016. Panduan Gerakan Literasi Sekolah Di Sekolah Dasar. Jakarta: Direktorat Jendral Pendidikan Dasar dan Menengah Kementrian Pendidikan dan Kebudayaan

Hasan, M. Iqbal. 2002. Pokok-pokok Materi Statistik 2. Jakarta: Bumi Aksara.

Kemendikbud. 2016a. Desain Induk Program Gerakan Literasi Sekolah (GLS). Jakarta: Ditjen Dikdasmen, Kemendikbud

Kemendikbud. 2016b. Panduan Gerakan Literasi Sekolah di Sekolah Dasar. Jakarta: Direktorat Jenderal Pendidikan Dasar dan Menengah Kementerian Pendidikan dan Kebudayaan.

Kern, R. 2000. Literacy and Language Teaching. Oxford: Oxford University Press. 
Kern, R. 2002. Reconciling the Language-Literatur Split Through Literacy. AFDL Bulletin, 33 (3): hlm. 1-11, (Online), (http:www.afdl.org/bulletin/ Index. html), diakses: 7 November 2016.

Miller, John W dan McKenna, Michael C. 2016. World Literacy: How Countries Rank and Why It Matters. London: Routledge

Rahim, Farida. 2011. Pengajaran Membaca di Sekolah Dasar. Bumi Aksara. Jakarta.

Rahim, Farida. 2011. Pengajaran Membaca di Sekolah Dasar. Jakarta: Bumi Aksara.

Sardiman, A.M. 2012. Interaksi dan Motivasi Belajar Mengajar. PT. Raja Grafindo Persada. Jakarta

Shaleh, Abdul Rahman \& Wahab, Muhbib Abdul. 2007. Psikologi Suatu Pengantar dalam Persfektif Islam. Kencana. Jakarta.

Slameto. 2013. Belajar dan Faktor-faktor yang mempengaruhinya. Bumi Aksara. Jakarta

Syah, Muhibbin. 2013. Psikologi Pendidikan dengan Pendekatan Baru. PT. Remaja Rosdakarya. Bandung.

Sugiyono. 2012. Metode Penelitian Pendidikan Pendekatan Kuantitatif, kualitatif dan R\&D. Bandung: Alfabeta. 